\title{
Overexpression of PAD1 and FDC1 results in significant cinnamic acid decarboxylase activity in Saccharomyces cerevisiae
}

\author{
Peter Richard*, Kaarina Viljanen and Merja Penttilä
}

\begin{abstract}
The S. cerevisiae PAD1 gene had been suggested to code for a cinnamic acid decarboxylase, converting trans-cinnamic acid to styrene. This was suggested for the reason that the over-expression of PAD1 resulted in increased tolerance toward cinnamic acid, up to $0.6 \mathrm{mM}$. We show that by over-expression of the PAD1 together with the FDC1 the cinnamic acid decarboxylase activity can be increased significantly. The strain over-expressing PAD1 and FDC1 tolerated cinnamic acid concentrations up to $10 \mathrm{mM}$. The cooperation of Pad1p and Fdc1p is surprising since the PAD1 has a mitochondrial targeting sequence and the FDC1 codes for a cytosolic protein. The cinnamic acid decarboxylase activity was also seen in the cell free extract. The activity was $0.019 \mu \mathrm{mol}$ per minute and $\mathrm{mg}$ of extracted protein. The overexpression of PAD1 and $F D C 1$ resulted also in increased activity with the hydroxycinnamic acids ferulic acid, p-coumaric acid and caffeinic acid. This activity was not seen when FDC1 was overexpressed alone.

An efficient cinnamic acid decarboxylase is valuable for the genetic engineering of yeast strains producing styrene. Styrene can be produced from endogenously produced L-phenylalanine which is converted by a phenylalanine ammonia lyase to cinnamic acid and then by a decarboxylase to styrene.
\end{abstract}

Keywords: Cinnamic acid; Styrene; Decarboxylase; S. cerevisiae; PAD1; FDC1

\section{Introduction}

Enzymes for the decarboxylation of hydroxycinnamic acids such as p-coumaric acid, caffeic acid or ferulic acid have been described. A ferulic acid decarboxylase and the corresponding gene, $f d c$, was identified from Bacillus pumilus (Zago et al. 1995). A ferulic acid decarboxylase was also identified from an Enterobacter species (Gu et al. 2011a) and a crystal structure obtained (Gu et al. 2011b). A p-coumaric acid decarboxylase was purified from Lactobacillus plantarum. The enzyme was inducible and the purified enzyme had a $\mathrm{K}_{\mathrm{M}}$ of $1.4 \mathrm{mM}$ and a $\mathrm{K}_{\text {cat }}$ of $10^{3} \mathrm{~s}^{-1}$ (Cavin et al. 1997b). The corresponding gene, $p d c$, was cloned and overexpressed in E. coli (Cavin et al. 1997a). This protein was crystallised and a structure obtained (Rodríguez et al. 2010). Based on the homology to the $f d c$ and $p d c$ a hydroxycinnamic acid (phenolic acid) decarboxylase, pad, was identified in Bacillus subtilis (Cavin et al. 1998). These hydroxycinnamic

\footnotetext{
* Correspondence: Peter.Richard@vtt.fi

VIT Technical Research Centre of Finland Ltd, Tietotie 2, P.O. box 1000, 02044 VTT Espoo, Finland
}

acid decarboxylases were shown to be active in vivo and in vitro and the purified enzymes did not require cofactors and were not part of multi subunit enzyme complexes. All these enzymes have in common that they are of bacterial origin and not active with cinnamic acid.

The yeast Saccharomyces cerevisiae shows some resistance toward cinnamic acid and the gene that confers this resistance was identified as the PAD1 (phenylacrylic acid decarboxylase) gene (Clausen et al. 1994). The yeast can convert cinnamic acid to styrene (Figure 1) but also sorbic acid to 1,3-pentadiene however with a lower rate. The deletion of $P A D 1$ resulted in the inability to convert cinnamic or sorbic acid suggesting that the Pad1p is active with both substrates (Stratford et al. 2007). Overexpression of the PAD1 gene resulted in strains with increased resistance to cinnamic and ferulic acid (Larsson et al. 2001). A PAD1 homologue is also present in the mold Aspergillus niger where it confers resistance to cinnamic acid and sorbic acid (Plumridge et al. 2008). Recently it was shown in S. cerevisiae that not only the PAD1 but the $P A D 1$ and the $F D C 1$ are essential for cinnamic acid, 


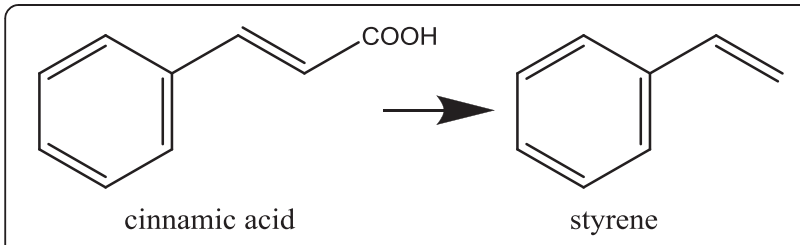

Figure 1 Trans-cinnamic acid is converted in a decarboxylation reaction to styrene.

ferulic acid or coumaric acid resistance. Deletions in either of these two genes resulted in drastic reduced ability to decarboxylate these acids (Mukai et al. 2010). A possible interpretation of this observation was that the Pad1p and the Fdc1p are two essential subunits of a protein complex. The Pad1p and the Fdc1p are however believed to be in different cellular compartments. The Pad1p has a mitochondrial targeting sequence and the protein is located in the mitochondria (Huh et al. 2003) whereas the Fdc1p is a cytosolic protein.

The PAD1 and the FDC1 are clustered, i.e. they are located next to each other on the chromosomes. Such clusters with PAD1 and FDC1 homologues are widespread in yeast and filamentous fungi. In filamentous fungi the cluster contains also a transcription factor (Plumridge et al. 2010).

Cinnamic acid decarboxylase is required for the genetic engineering of styrene producing strains. Styrene can be produced from endogenous L-phenylalanine in two steps, by a phenylalanine ammonia lyase to produce cinnamic acid and a cinnamic acid decarboxylase producing styrene (McKenna and Nielsen 2011, McKenna et al. 2014). An efficient cinnamic acid decarboxylase would be desirable for the construction of strains for effective styrene production from biomass.

\section{Materials and methods Strains and plasmids}

Strains: The yeast strain CEN.PK2-1C was obtained from Prof. Friedrich K. Zimmermann (Frankfurt) and used if not otherwise specified.

Plasmids: PAD1 and FDC1 were amplified from S. cerevisiae by PCR. The PAD1 was amplified from genomic DNA of the yeast strain S288C (obtained from Dr. G. Shirleen Roeder, Yale), FDC1 from the CEN.PK2-1C. Through PCR EcoRI and NheI sites were introduced and then ligated to the corresponding sites of p2159 and p2158. The p2159 was derived from the pYX212, a multicopy yeast expression vector with URA3 marker and TPI1 promoter, by changing the multiple cloning site as described before (Kuorelahti et al. 2005). The p2158 is derived in the same way from the pYX242, a multicopy yeast expression vector with LEU2 marker and TPI1 promoter. The PAD1 was also amplified by PCR introducing XhoI and EcoRI sites and then ligated to the
pFL60 (Minet et al. 1992), a multicopy yeast expression vector with $U R A 3$ marker and PGK1 promoter. The PAD1 was also amplified by PCR without mitochondrial targeting signal. The mitochondrial targeting sequence was identified using the MitoProt software (http://ihg. gsf.de/ihg/mitoprot.html). In one case the first amino acid after the cleavage site was replaced by the start codon so that the amino acid sequence was MVAITG.... In another case the start codon was before the first amino acid resulting in the sequence MVVAITG.... An $F D C 1$ with mitochondrial targeting sequence was generated by adding the first 60 amino acids of the PAD 1 to the $\mathrm{N}$-terminus of the $F D C 1$ open reading frame. The plasmids are listed in the Table 1.

\section{Enzyme activity measurement}

To prepare a cell free yeast extract yeast cells were collected by centrifugation, washed with water and $1 \mathrm{ml}$ of fresh cell cake was suspended in $1 \mathrm{ml} 20 \mathrm{mM}$ sodium phosphate buffer $\mathrm{pH} 7.0 .1 \mathrm{ml}$ of glass beads $(0.4 \mathrm{~mm}$ diameter, Sigma) and protease inhibitor (Complete, Roche) were added and the cells were disrupted in two 40s sessions in the Fast Prep (Bio101). The cell extract was centrifuged and the supernatant analysed for cinnamic acid decarboxylase activity. The protein concentration was measured using the Biorad Protein Assay and BSA as a standard. The extract was added to a solution of cinnamic acid in $20 \mathrm{mM}$ sodium phosphate, $\mathrm{pH}$ 7.0, and incubated at room temperature. The reaction was quenched by heating the sample to $96^{\circ} \mathrm{C}$ for 10 minutes.

Cinnamic acid and hydroxy-cinnamic acids were determined by using an analytical UPLC method. The separation of analytes was carried out on an Acquity UPLC BEH C18 $1.7 \mu \mathrm{m}$ column $(2.1 \times 100 \mathrm{~mm})$ with a Waters Acquity UPLC system including sample manager-FTN, Quaternary solvent manager and PDA e $\lambda$ detector. Detector was operated on 210-400 $\mathrm{nm}$. The solvents used in gradient elution $0.43 \mathrm{~mL} / \mathrm{min}$ were A) $5 \%$ formic acid and B) acetonitrile. Gradient system was as followed: $0 \min 95 \% \mathrm{~A}$ and $5 \% \mathrm{~B} ; 1.13 \min 90 \% \mathrm{~A}$ and $10 \% \mathrm{~B}$; $5.67 \mathrm{~min} 60 \% \mathrm{~A}$ and $40 \% \mathrm{~B} ; 9.00 \mathrm{~min} 10 \% \mathrm{~A}$ and $90 \% \mathrm{~B}$; and $10.00 \mathrm{~min} 90 \% \mathrm{~A}$ and $10 \% \mathrm{~B}$. On the basis of

Table 1 Table of plasmids used

\begin{tabular}{lll}
\hline Plasmid name & Gene expressed & Parent plasmid \\
\hline p4237 & FDC1 & p2159 (URA3) \\
p4517 & FDC1 & p2158 (LEU2) \\
p4621 & PAD1 & pFL60 (URA3) \\
p4596 & PAD1 without targeting (MVAITG...) & pFL60 (URA3) \\
p4597 & PAD1 without targeting (MVAITG...) & pFL60 (URA3) \\
p4787 & FDC1 with mitochondrial targeting & p2158 (LEU2) \\
\hline
\end{tabular}


corresponding standards $(0-1000 \mu \mathrm{M})$ compounds were quantified.

\section{Analysis of styrene by SPME-GC/MS}

Samples $(300 \mu \mathrm{l})$ were analyzed by using SPME (solid phase micro extraction)-GC/MS. Extraction of styrene was done at $80^{\circ} \mathrm{C}$ for $30 \mathrm{~min}$ with preconditioned $\left(300^{\circ} \mathrm{C}\right.$, $60 \mathrm{~min}$ ) $75 \mu \mathrm{m}$ Carboxen-PDMS fibre (Sulpelco, USA). After extraction the analytes were desorbed during $5 \mathrm{~min}$ at $250^{\circ} \mathrm{C}$ in the splitless injector (flow $14.9 \mathrm{ml} / \mathrm{min}$ ) of the gas chromatography (Agilent 6890 Series; Palo Alto, CA, USA) combined with a MS detector (Agilent 5973Network MSD, USA) and SPME autosampler (Combipal, Varian Inc., USA). Analytes were separated on BPX 5 capillary column of $60 \mathrm{~m} \times 0.25 \mathrm{~mm}$ with a phase thickness $1.0 \mu \mathrm{m}$ (SGE Analytical Science Pty Ltd, Australia). $\alpha$-Pinene was used as internal standard. The temperature programme started at $60^{\circ} \mathrm{C}$ with 1 min holding time, then increased $7^{\circ} \mathrm{C} / \mathrm{min}$ up to $100^{\circ} \mathrm{C}$, followed by $10^{\circ} \mathrm{C} / \mathrm{min}$ increase up to final temperature $200^{\circ} \mathrm{C}$, where the temperature was kept for $4 \mathrm{~min}$. MSD was operated in electron-impact mode at $70 \mathrm{eV}$, in the full scan $\mathrm{m} / \mathrm{z} 40-550$. The ion source temperature was $230^{\circ} \mathrm{C}$ and the interface was $280^{\circ} \mathrm{C}$. Styrene was identified with corresponding standard and by comparing the mass spectra on Palisade Complete $600 \mathrm{~K}$ Mass Spectral Library (Palisade Mass Spectrometry, USA).

\section{Results}

\section{In vitro activity}

It was previously shown that the $P A D 1$ is responsible for cinnamic acid dehydratase activity and that the overexpression of PAD1 results in increased cinnamic acid dehydratase activity (Clausen et al. 1994, Larsson et al. 2001) using intact cells of $S$. cerevisiae. In order to test if this activity could be also seen in cell free extracts we analysed the cell free extracts of the CEN.PK strains which were not modified or expressed the PAD1 gene. The PAD1 gene was amplified from the $S$. cerevisiae strain S288C since the CEN.PK has a mutation in the $P A D 1$ gene resulting in a stop codon instead of the tyrosine in position 98. The cell extracts were incubated with $500 \mu \mathrm{M}$ cinnamic acid at neutral $\mathrm{pH}$ and the disappearance of cinnamic acid was followed by UPLC, however no decarboxylase activity was detected. We followed the decrease in cinnamic acid over a period of 5 hours at a protein concentration of $2 \mathrm{~g} / \mathrm{l}$ but could not detect a decrease. The detection limit for the decrease in concentration was estimated $15 \mu \mathrm{M}$. We also tested if the overexpression of $F D C 1$ would result cinnamic acid decarboxylase activity in the cell free extract however no activity was detected. However when the two cell-free extracts with PAD1 and the extracts with $F D C 1$ were mixed, cinnamic acid decarboxylase activity was detected. After 5 hours the cinnamic acid concentration was decreased by $250 \mu \mathrm{M}$. This suggested that both enzymes, Pad1p and Fdc1p, are required. We then expressed PAD1 and FDC1 in the same yeast strain using two multicopy plasmids. This extract had a much higher cinnamic acid decarboxylase activity. This is summarized in the Figure 2. The initial rate was about $0,019 \mu \mathrm{mol}$ per minute and $\mathrm{mg}$ of extracted protein. We also confirmed that the reaction product was styrene.

\section{In vivo activity}

The $P A D 1$ gene has a mitochondrial targeting sequence of 57 amino acids and the Pad1p is believed to be a mitochondrial protein. The FDC1 gene however has no targeting sequence and the Fdc1p is believed to be a cytosolic protein. To test if Pad1p and Fdc1p are also active in vivo we tested the sensitivity toward cinnamic acid. For that purpose we plated the yeast strain overexpressing the PAD1 and $F D C 1$ on selective plates with increasing amounts of cinnamic acid. At concentrations of up to $10 \mathrm{mM}$ cinnamic acid growth was observed. In the control concentrations above $100 \mu \mathrm{M}$ were toxic (Table 2). The pKa for cinnamic acid is 4.44. Since the medium was not buffered, the cinnamic acid is in its salt form and it is actually cinnamate resistance that was observed.

\section{Mitochondrial targeting}

The combination of PAD1 and FDC1 seemed to result in cinnamic acid decarboxylase activity although the proteins are targeted to different cellular compartments. We tested if the activity could be increased by targeting the proteins to the same cellular compartment. In one case we targeted both proteins to the mitochondria. For that purpose we added the mitochondrial targeting

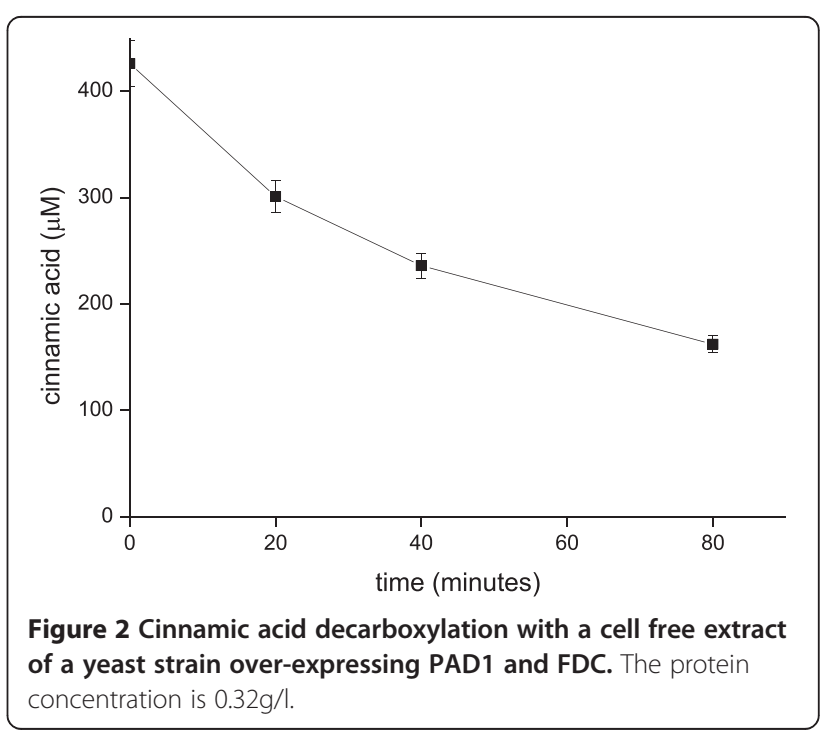


Table 2 Growth on increasing cinnamic acid concentrations

\begin{tabular}{lcc}
\hline Cinnamic acid concentration & H4086 & Control \\
\hline $30 \mathrm{mM}$ & - & - \\
$20 \mathrm{mM}$ & - & - \\
$10 \mathrm{mM}$ & + & - \\
$5 \mathrm{mM}$ & + & - \\
$3 \mathrm{mM}$ & + & - \\
$1 \mathrm{mM}$ & + & - \\
$500 \mu \mathrm{M}$ & + & - \\
$100 \mu \mathrm{M}$ & + & + \\
\hline
\end{tabular}

In the strain H4086 PAD1 and FDC1 are expressed from two multicopy plasmids. The control strain harbours the plasmids without open reading frames.

sequence of the PAD1 to the FDC1. In the other case we targeted both to the cytosol. For that we removed the targeting signal from the $P A D 1$. In both cases the cell free extract of the yeast strain over-expressing both genes, $P A D 1$ and $F D C 1$ with added targeting sequence or FDC1 and $P A D 1$ with removed targeting sequence, showed no cinnamic acid decarboxylase activity. Removing or adding mitochondrial targeting signals might affect the protein folding, the lack of activity is therefore not necessarily related to the targeting.

\section{Activity with hydroxy-cinnamic acids}

We tested the activity with the following hydroxylcinnamic acids in cell free extracts: p-coumaric acid, ferulic acid and caffeic acid. When the PAD1 or FDC1 were over-expressed alone we could not detect decarboxylase activity. However, when overexpressing PAD1 and FDC1 together we observed activity. This is summarized in the Figure 3. The highest activity was observed with ferulic acid, but this activity was still lower that with cinnamic acid.

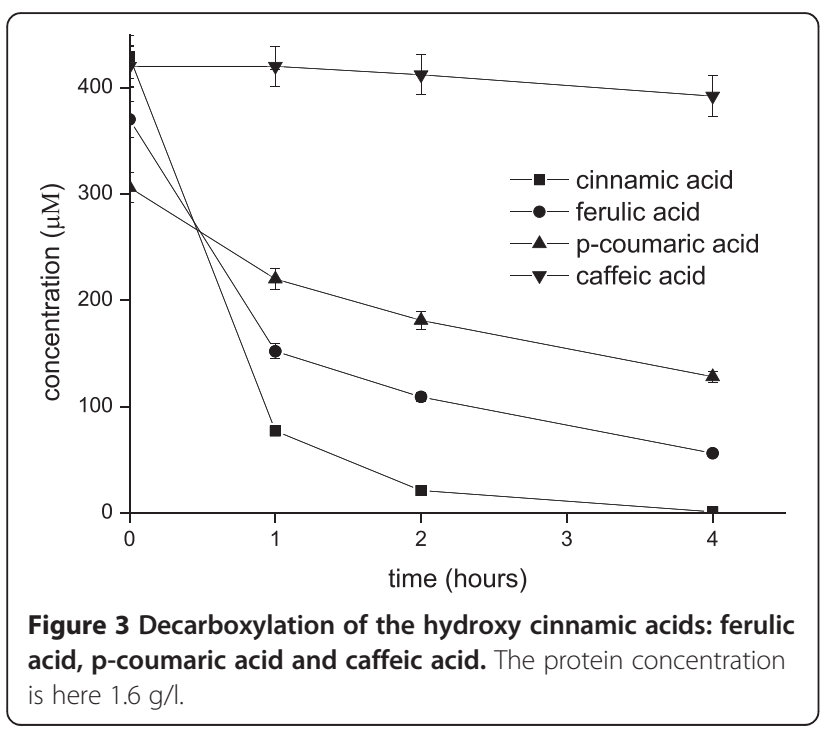

\section{Discussion}

Although it is known that yeast and other microorganisms have the ability to convert cinnamic acid to styrene, the enzyme to catalyse this reaction has not been identified. This is mainly because most of the studies were carried in vivo and only a few used a cell free environment (Mukai et al. 2010, Stratford et al. 2012).

In $S$. cerevisiae the PAD1 was suggested to code for the cinnamic acid decarboxylase. A PAD1 mutant showed increased sensitivity toward cinnamic acid and expression of PAD1 repaired the phenotype (Clausen et al. 1994). In the same study permeabilised cells were used to measure cinnamic acid decarboxylase activity. The parent strain showed an activity of $0-3.9 \mathrm{nM} / \mathrm{mg}$ dry mass per $\mathrm{h}$ and after expression of PAD1 $29.4 \mathrm{nM} / \mathrm{mg}$ dry mass per h (Clausen et al. 1994). Assuming that $40 \%$ of the dry mass is extractable protein this would correspond to about $75 \mathrm{nM}$ per mg extracted protein and hour. When we overexpressed FDC1 and PAD1 and analysed the cell extract we estimated the decarboxylase activity to be about $1 \mathrm{mM}$ per $\mathrm{mg}$ extracted protein and hour. This corresponds to an increase of activity of about 4 orders of magnitude.

The Pad1p and the Fdc1p are located in different compartments in S. cerevisiae. The Pad1p is in mitochondria and the Fdc1p in the cytosol. The fact that the overexpression of both proteins results in an increased resistance toward cinnamic acid can be interpreted in different ways. One interpretation is that cinnamic acid is converted to styrene in two steps with an intermediate that is passing through the mitochondrial membrane. Another interpretation is that the proteins are not confined to their compartment. However for the Pad1p it was shown that after tagging with the green fluorescence protein the enzyme was exclusively located in the mitochondria (Huh et al. 2003).

No information is available about a possible protein complex including Pad1p and Fdc1p. In an genome wide survey to identify protein complexes by systematic tagging of open reading frames to identify protein complexes, no protein complexes with Pad1p or Fdc1p were identified (Gavin et al. 2006).

The physiological role of cinnamic acid decarboxylation is detoxification. Cinnamic acid or cinnamate is more toxic than the reaction product styrene. Cinnamic acid decarboxylation is also of potential biotechnological relevance. L-Phenylalanine can be efficiently converted to cinnamic acid by the action of an L-phenylalanine ammonia lyase (PAL). PAL and cinnamic acid decarboxylase constitute a pathway for styrene production from Lphenylalanine. This had been practiced by McKenna et al. in $E$. coli to produce styrene from D-glucose (McKenna and Nielsen, 2011). In this work the PAD1 and the FDC1 of S. cerevisiae were expressed in E. coli 
but it was concluded that functional cinnamic acid decarboxylase activity in E. coli depends solely upon FDC1 over-expression and is not dependent on co-expression of PAD1. The expression of the S.cerevisiae PAD1 in E. coli did not result in cinnamic acid decarboxylation activity; however the combined expression of $P A D 1$ and $F D C 1$ resulted in such activity. The expression of FDC1 alone also resulted in activity suggesting that the PAD1 is not required for activity; however it cannot be excluded that an E. coli protein homologous to PAD1 would be functional (McKenna and Nielsen, 2011). There are indeed proteins in $E$. coli with homologies to the PAD1. One is the $U b i X$ that has a role in coenzyme $\mathrm{Q}$ biosynthesis (Gulmezian et al. 2007). Another one is a close homologue, Pad1, that has been crystallized and a structure determined (Rangarajan et al. 2004), however no function was assigned.

\section{Competing interests}

The authors declare that they have no competing interests.

\section{Acknowledgement}

This work was supported by the Academy of Finland through the Sustainable Energy (SusEn) programme (Grant 271025).

Received: 7 January 2015 Accepted: 9 February 2015

Published online: 18 February 2015

\section{References}

Cavin JF, Barthelmebs L, Diviès C (1997a) Molecular characterization of an inducible p-coumaric acid decarboxylase from Lactobacillus plantarum: gene cloning, transcriptional analysis, overexpression in Escherichia coli, purification, and characterization. Appl Environ Microbiol 63:1939-1944

Cavin JF, Barthelmebs L, Guzzo J, Van Beeumen J, Samyn B, Travers J-F, Diviès C (1997b) Purification and characterization of an inducible $p$-coumaric acid decarboxylase from Lactobacillus plantarum. FEMS Microbiol Lett 147:291-295

Cavin JF, Dartois V, Diviès C (1998) Gene cloning, transcriptional analysis, purification, and characterization of phenolic acid decarboxylase from Bacillus subtilis. Appl Environ Microbiol 64:1466-1471

Clausen M, Lamb CJ, Megnet R, Doerner PW (1994) PAD1 encodes phenylacryil acid decarboxylase which confers resistance to cinnamic acid in Saccharomyces cerevisiae. Gene 142:107-112

Gavin AC, Aloy P, Grandi P, Krause R, Boesche M, Marzioch M, Rau C, Jensen L, Bastuck S, Dümpelfeld B, Edelmann A, Heurtier MA, Hoffman V, Hoefert C, Klein K, Hudak M, Michon AM, Schelder M, Schirle M, Remor M, Rudi T, Hooper S, Bauer A, Bouwmeester T, Casari G, Drewes G, Neubauer G, Rick JM, Kuster B, Bork P, Russell RB, Superti-Furga G (2006) Proteome survey reveals modularity of the yeast cell machinery. Nat Chem Biol 440:631-636

Gu W, Li X, Huang J, Duan Y, Meng Z, Zhang KQ, Yang J (2011a) Cloning, sequencing, and overexpression in Escherichia coli of the Enterobacter sp. Px6-4 gene for ferulic acid decarboxylase. Appl Microbiol Biotechnol 89:1797-1805

Gu W, Yang J, Lou Z, Liang L, Sun Y, Huang J, Li X, Cao Y, Meng Z, Zhang KQ (2011b) Structural basis of enzymatic activity for the ferulic acid decarboxylase (FADase) from Enterobacter sp. Px6-4. PLoS One 6:e16262

Gulmezian M, Hyman KR, Marbois BN, Clarke CF, Javor GT (2007) The role of UbiX in Escherichia coli coenzyme Q biosynthesis. Arch Biochem Biophys 467:144-153

Huh W-K, Falvo JV, Gerke LC, Carroll AS, Howson RW, Weissman JS, O'Shea EK (2003) Global analysis of protein localization in budding yeast. Nature 425:686-691

Kuorelahti S, Kalkkinen N, Penttilä M, Londesborough J, Richard P (2005) Identification in the mold Hypocrea jecorina of the first fungal D-galacturonic acid reductase. Biochemistry 44:11234-11240

Larsson S, Nilvebrant N-O, Jönsson $\sqcup$ (2001) Effect of overexpression of Saccharomyces cerevisiae Pad1p on the resistance to phenylacrylic acids and lignocellulose hydrolysates under aerobic and oxygen-limited conditions. Appl Microbio Biotechnol 57:167-174

McKenna R, Nielsen DR (2011) Styrene biosynthesis from glucose by engineered E. coli. Metab Eng 13:544-554

McKenna R, Thompson B, Pugh S, Nielsen DR (2014) Rational and combinatorial approaches to engineering styrene production by Saccharomyces cerevisiae. Microb Cell Fact 13:123

Minet M, Dufour ME, Lacroute F (1992) Complementation of Saccharomyces cerevisiae auxotrophic mutants by Arabidopsis thaliana cDNAs. Plant I 2:417-422

Mukai N, Masaki K, Fujii T, Kawamukai M, lefuji H (2010) PAD1 and FDC1 are essential for the decarboxilation of phenylacrylic acid in Saccharomyces cerevisiae. J Biosci Bioeng 109:564-569

Plumridge A, Stratford M, Lowe KC, Archer DB (2008) The weak-acid preservative sorbic acid is decarboxylated and detoxified by a phenylacrylic acid decarboxylase, PadA1, in the spoilage mold Aspergillus niger. Appl Environ Microbiol 74:550-552

Plumridge A, Melin P, Stratford M, Novodvorska M, Shunburne L, Dyer PS, Roubos JA, Menke H, Stark J, Stam H, Archer DB (2010) The decarboxylation of the weak-acid preservative, sorbic acid, is encoded by linked genes in Aspergillus spp. Fungal Genet Biol 47:683-692

Rangarajan ES, Li Y, lannuzzi P, Cygler M, Matte A (2004) Crystal structure of Escherichia coli crotonobetainyl-CoA: carnitine CoA-transferase (CaiB) and its complexes with CoA and carnitinyl-CoA. Biochemistry 44:5728-5738

Rodríguez H, Angulo I, DelasRivas B, Campillo N, Páez JA, Muñoz R, Mancheño JM (2010) p-Coumaric acid decarboxylase from Lactobacillus plantarum Structural insights into the active site and decarboxylation catalytic mechanism. Proteins 78:1662-1676

Stratford M, Plumridge A, Archer DB (2007) Decarboxylation of sorbic acid by spoilage yeasts is associated with the PAD1 gene. Appl Environ Microbiol 73:6534-6542

Stratford M, Plumridge A, Pleasants MW, Novodvorska M, Baker-Glenn CAG, Pattenden G, Archer DB (2012) Mapping the structural requirements of inducers and substrates for decarboxylation of weak acid preservatives by the food spoilage mould Aspergillus niger. Int J Food Microbiol 157:375-383

Zago A, Degrassi G, Bruschi CV (1995) Cloning, sequencing, and expression in Escherichia coli of the Bacillus pumilus gene for ferulic acid decarboxylase. Appl Environ Microbiol 61:4484-4486

\section{Submit your manuscript to a SpringerOpen ${ }^{\odot}$ journal and benefit from:}

- Convenient online submission

Rigorous peer review

- Immediate publication on acceptance

- Open access: articles freely available online

- High visibility within the field

- Retaining the copyright to your article

Submit your next manuscript at $\gg$ springeropen.com 